\title{
Compulsory Health Insurance Local Funds Reserve System Problems
}

\author{
Margarita Sh. Irizepova \\ Volgograd State University, \\ Institute of Economics and Finance \\ Chair of Theory of Finance, Credit and Tax \\ Volgograd, Russia \\ irizepovams@volsu.ru
}

\begin{abstract}
CHI Local funds should create several types of reserves to ensure the financial sustainability of Local CHI system. However, the analysis shows that in practice, the reserves are not created at all.
\end{abstract}

Keywords-CHI Local funds, reserves, temporarily free funds, temporarily available funds placement, normalized insurance reserve (NIR) of the CHILF (Compulsory Health Insurance Local Fund)

\section{INTRODUCTION}

The topicality of the reserve system of local compulsory health insurance funds study is approved by the lack of data in regional and federal statistics on financial reserves created in them, while Law No. 326 "On Compulsory Medical Insurance" dwells upon the creation of several of types of such reserves. The reason for the norms of law and practice discrepancy is explained in the article. The purpose of the article is to show that modern CHILF cannot independently ensure the financial sustainability of $\mathrm{CHI}$ in the territory of their operation.

\section{MATERIALS AND Methods (MODEL)}

The regional level of the CHI system is presented by Local CHI funds (CHILFs). In December 20, 2017, there were 86 CHILFs on the Russian Federation territory. The founders of the CHILFs are the subjects of the Russian Federation. In accordance with Art. 34 of Law No. 326-FL, the CHILF accumulates and controls the $\mathrm{CHI}$ funds,

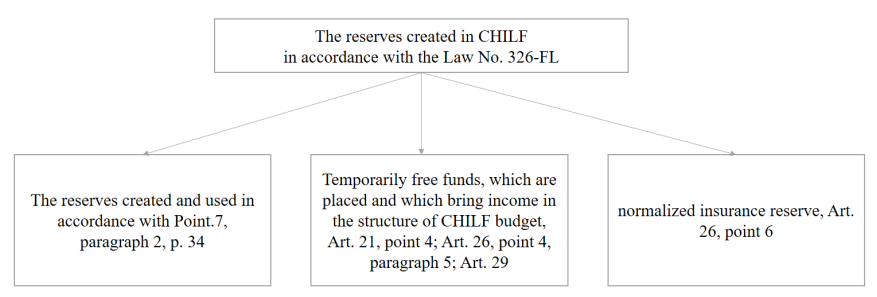
FL.

Fig. 1. Reserves created by CHIFF in accordance with the Law No. 326- provides financial support for the implementation of local CHI programs in the constituent entities of the Russian Federation, forms and uses reserves (highlighted by the author - the author's commentary) to ensure the financial stability of $\mathrm{CHI}$ in the order established by the CHIFF (Compulsory Health Insurance Federal Fund).

According to the points in of Law No. 326-FL [1], in Fig. 1 all the types of reserves that can be created in the CHIFF, and which are mentioned therein were indicated in the paper.

\section{RESULTS AND DISCUSSION}

In the process of the analysis it has been established that the Reserves for the financial stability of CHI ensuring in any subject of the Russian Federation are not regulated from the legal point of view. In the text of Law No. 326-FL, the term "reserve" is mentioned only twice - once in describing the budget of the CHIFF, the second time - in describing the budget of the CHILF. Even though in paragraph 7, point 2, art. 34 it is stated that this reserve is created according to the law established by the CHIFF, not any documents that would reflect its provisions were found. Additional searches of the formation procedure of this reserve in the Provisions on the CHILF in the constituent entities of the Russian Federation also did not yield any result. In the regions such as Moscow, Volgograd, Rostov, Novosibirsk, Leningrad and some other regions (in total, 15 subjects of the Russian Federation that were included in the research), there are no references to the Reserves providing financial stability of the $\mathrm{CHI}$ in the Provisions on their CHILF. This information is also missing on the CHIFF official website, where the main regulatory documents containing information about its tasks and functions are published.

This allowed us to conclude that in this part the law No. 326-FL requires further development. It should specify which criteria should be used to determine the financial sustainability of the CHI system in the constituent entities of the Russian Federation, what risks it may face, and by what financial instruments it can be regulated. In addition, it is necessary to indicate which financial reserves are necessary to maintain financial stability in normal condition, how they should be formed, placed, used and who they should be controlled by. 
Besides, the location of this reserve as part of the CHILF budget should be necessarily determined. At present, not only for the CHI system (both CHILF and CHIFF), all the budgets are usually described only by transferring the composition of their incomes and expenditures, but also indicating the sources of deficit regulation, if it arises. The domestic budget system does not allocate a special section, which contains information only about the composition and the amount of the reserves formed, especially about perfect reserves, which can be placed on investment sites to preserve and increase their cost. Meanwhile, the absence of this section leads to insufficient transparency of the reporting data. In extreme cases, data on the composition of reserves is published in the additional material in the form of references.

Other reserves of the CHILF are described in more detail in Law No. 326-FL. For the regulation of temporarily free funds of $\mathrm{CHI}$ and their placement there is article 29, for implementation of which RF Government Decree No. 1225 of December 31, 2010 [2] has been developed and is in force. However, it should be noted that neither in Article 29 nor in the specified Resolution of the Russian Federation Government there is a definition of temporarily available funds. The RF Government Resolution No. 1225 provides only an approach for calculating their size. It is circled around comparing the CHILF budget cash management planning and the state of its account in the Federal Treasury data. Based on this, it can be assumed that temporarily the funds in the CHILF account, exceeding their amount fixed in the cash plan of the CHILF budget execution, will be considered as free. In other words, the CHILF should constantly analyze data on the enrollment and withdrawal of funds from its account and plan data on its cash balances. If money accumulated on the account of the CHILF is not planned to be used in the current turnover in the near future, it can be considered temporarily free and be placed to preserve or increase their value. The characteristics outlined to describe temporarily available funds are similar to the characteristics of reserves. Reserves are also not involved in current consumption, and perfect reserves, as a rule, are placed on different investment sites. Therefore, it is believed that it is quite possible to treat temporarily available funds as cash planning reserves.

In accordance with the provisions of Government Decree No. 1225, temporary free CHILF can be placed on bank deposits. The most essential condition for placing temporary free funds of the CHILF is the possibility of early repayment of the amount (part of the amount) of the deposit at the request. The need for early repayment is justified in the Resolution by the cash disruptions probability. That is why, there is a norm in it, according to which the CHILF is obliged to make an early withdraw of temporarily available free funds in the event of a temporary cash gap in the amount that will ensure its coverage, and in the time required for crediting the amounts of funds placed on the single account of the CHILF budget.

Credit organizations, in which it is planned to place deposits, are selected with the help of a competition by applying to special Internet portals. The decision of temporarily free funds of the CHILF placement is taken by the directors of the local funds.
After deposits opening, the CHILF daily checks the compliance of credit institutions with these requirements. In case when the credit institution has ceased to comply with the provisions specified in Resolution No. 1225, the CHILF has the right to send the request for an immediate return of the deposit amount placed in this credit institution.

Note that the income from the temporarily free funds placement in a separate line in statistical forms of the CHILF reporting (Form 9-F CHI) [3] is not reflected, i.e. their isolation in the performance report is not indicated. In accordance with the order of the Federal State Statistics Service, they should be included in the "Revenues from the use of property in state and municipal ownership" line 08, Income section (code $395 \quad 1 \quad 1102072090000$ 120). In addition to income from the temporarily available funds placement, this line also reflects the income from property leasing in the operational management of the CHILF and other income from the property use. This fact can show either the absence of incoming funds, or their insignificance, or the irregularity of receipts, or all these factors at the same time.

The Table contains figures from federal statistics on income and expenditure of the CHILF funds on the Russian Federation territory. These data indicate that the share of income from the use of state and municipal property is negligible and amounts at $0.0006 \%$ in 2011 up to $0.064 \%$ in 2009. If all these factors are taken into account, the incomes from the placement of temporarily available funds are included in these types of incomes, that it becomes evident that these revenues are an insignificant revenue item. It cannot affect the financial stability of the territorial CHI funds in any way.

The other CHILF reserve can be considered Normalized Insurance Reserve (NIR). It is formed in the "Expenses" section of the CHILF budgets in accordance with Article 26 para. 6, Law No. 326-FL.

The total amount of CHILF NIR fund and the purpose of its usage should be established by the law on the local fund budget.

NIR is used for:

- additional financial support of local CHI programs implementation;

- payments for medical care rendered to insured persons outside the territory of the subject of the Russian Federation, in which the CHI policy is issued;

- financial support of measures on the organization of additional professional education of medical workers under the programs of advanced training, as well as the medical equipment acquisition and repairing.

Law No. 326-FL establishes different sources of formation for each direction of the NIR usage (see Figure 2).

For the first two directions, the source of the NIR formation is the redistributed income of the CHILF budget. The revenues of the CHILF budgets are formed in accordance with the budget legislation of the Russian Federation. They include:

1) subventions from the CHIFF budget to the CHILF budgets;

2) intergovernmental transfers passed from the CHIFF budget; 
3) subjects of the Russian Federation payments for additional financial support for the implementation of the local $\mathrm{CHI}$ program within the framework of the basic $\mathrm{CHI}$ program;

4) payments by the constituent entities of the Russian Federation offering financial support of additional types and conditions for the medical care not established by the basic CHI program provision;

5) the income from the temporarily available funds placement:

6) intergovernmental transfers passed from the subject of the Russian Federation budget in the cases established by the laws of the subject of the Russian Federation;

7) charged penalties and fines to be credited to the CHILF budgets;

8) other sources.

The amount of funds from the application of the local fund to medical organizations for sanctions identified while the monitoring of the scope, timing, quality and conditions of medical care provision is the same when forming NIR for the organization of additional professional education for health workers and for the medical equipment acquisition and repair.

TABLE I. LOCAL FUNDS OF COMPULSORY HEALTH INSURANCE INCOME AND EXPENDITURE (MILLION RUBLES). COMPOSED BY THE DATA OF FEDERAL STATISTICS [4]

\begin{tabular}{|c|c|c|c|c|c|c|c|c|}
\hline & 2009 & 2010 & 2011 & 2012 & 2013 & 2014 & 2015 & 2016 \\
\hline Income: total & $\begin{array}{l}551 \\
337\end{array}$ & $\begin{array}{l}574 \\
891\end{array}$ & $\begin{array}{l}904 \\
411\end{array}$ & $\begin{array}{l}1041 \\
908\end{array}$ & $\begin{array}{l}1227 \\
759\end{array}$ & 1417026 & $\begin{array}{l}1588 \\
618\end{array}$ & $\begin{array}{l}1637 \\
271\end{array}$ \\
\hline including & & & & & & & & \\
\hline $\begin{array}{ll}\text { Taxes, } & \text { insurance } \\
\text { premiums } & \text { Pan }\end{array}$ & $\begin{array}{l}162 \\
731\end{array}$ & $\begin{array}{l}183 \\
729\end{array}$ & $\begin{array}{l}226 \\
564\end{array}$ & 316 & 149 & 58 & 26 & -- \\
\hline $\begin{array}{l}\text { Income from the use } \\
\text { of property in state } \\
\text { and municipal } \\
\text { ownership }\end{array}$ & 353 & 150 & 6 & 93 & 251 & 321 & 214 & 47 \\
\hline Gratuitous receipts & $\begin{array}{l}377 \\
020\end{array}$ & $\begin{array}{l}376 \\
805\end{array}$ & $\begin{array}{l}656 \\
773\end{array}$ & $\begin{array}{l}1005 \\
887\end{array}$ & $\begin{array}{l}1200 \\
761\end{array}$ & 1415267 & $\begin{array}{l}1584 \\
609\end{array}$ & $\begin{array}{l}1626 \\
729\end{array}$ \\
\hline Expenditure: total & $\begin{array}{l}550 \\
616\end{array}$ & $\begin{array}{l}574 \\
166\end{array}$ & $\begin{array}{l}883 \\
479\end{array}$ & $\begin{array}{l}1036 \\
586\end{array}$ & $\begin{array}{l}1211 \\
261\end{array}$ & 1454862 & $\begin{array}{l}1595 \\
742\end{array}$ & $\begin{array}{l}1623 \\
990\end{array}$ \\
\hline including & & & & & & & & \\
\hline $\begin{array}{l}\begin{array}{l}\text { Providing } \\
\text { assistance } \\
\text { beneficiaries }\end{array} \\
\text { bocal } \\
\end{array}$ & 1123 & 923 & 810 & 1202 & 1395 & 6384 & 7183 & 7684 \\
\hline $\begin{array}{l}\text { Local CHI program } \\
\text { financing }\end{array}$ & $\begin{array}{l}508 \\
861\end{array}$ & $\begin{array}{l}535 \\
561\end{array}$ & $\begin{array}{l}657 \\
794\end{array}$ & 752906 & $\begin{array}{l}1185 \\
973\end{array}$ & 1380577 & $\begin{array}{l}1546 \\
231\end{array}$ & $\begin{array}{l}1552 \\
587\end{array}$ \\
\hline
\end{tabular}

Each of these two sources includes the same set of deductions:

1) 50 per cent of funds according to the results of medical and economic control;

2) 35 per cent of the sums unreasonably prescribed for payment by medical organizations, revealed because of the quality of medical care examination;

3) 35 per cent of sums unreasonably presented for payment by medical organizations, revealed because of medical and economic expertise;

4) 25 per cent of sums received because of fines for nonpresentation payment by the medical organization, giving medical assistance untimely or of inadequate quality;

At the same time, for the additional financial support for the local programs of CHI implementation, the amount of NIR funds is limited. It should not exceed the average monthly size of the planned local fund revenues for the next year. In other cases of the NIR usage, there has not been established any limits. CHILF maintain separate accounting in the spending the funds of the normalized insurance reserve directions.

Incidentally, it should be noted that additional financial support for the local CHI programs implementation can receive funds as a source of its financing from the NIR, which is formed in the CHIFF.
The NIR funds usage appears in Law No. 326-FL and relating to the agreement concluded by the CHILF and insurance medical organizations. The latter may apply for some of the NIR when their medical expenses are increased due to the increase in morbidity, the increase in tariffs for medical assistance payment, changes in the structure of insured persons by sex, age, leading to increased costs for paying bills of medical organizations. In these cases, the CHILF carries out a CHI financial audit and if it has not identified the remaining funds from the $\mathrm{CHI}$ or an unreasonable request for additional resources,

\begin{tabular}{|c|c|c|}
\hline & \multicolumn{2}{|c|}{ NIR FORMATION SOURCES } \\
\hline & $\begin{array}{l}\text { Redistributed CHILF income, } \\
\text { Art. } 26 \text {, point } 6.1\end{array}$ & $\begin{array}{l}\text { the usage of CHILF to medical } \\
\text { organizations funds for sanctions } \\
\text { for violations found during the } \\
\text { scope, timing, quality monitoring } \\
\text { and presentation of medical care } \\
\text { conditions; } \\
\text { Art. 26, points } 6.2,6.3 \text {. }\end{array}$ \\
\hline $\begin{array}{l}\text { NIR USAGE } \\
\text { DIRECTIONS }\end{array}$ & $\begin{array}{l}\text { - additional financial support for the } \\
\text { local CHI programs } \\
\text { implementation; } \\
\text { - payments for medical assistance } \\
\text { rendered to insured persons outside } \\
\text { the territory of the subject of the } \\
\text { Russian Federation, in which the } \\
\text { CHI policy was issued }\end{array}$ & $\begin{array}{l}\text { - organization of medica } \\
\text { workers additional professiona } \\
\text { education in the professiona } \\
\text { development programs; } \\
\text { - medical equipment purchas } \\
\text { and maintenance }\end{array}$ \\
\hline
\end{tabular}

Fig. 2. Usage and sources of the CHILF standardized insurance reserve formation directions.

the requested funds are allocated from the NIR. However, the grounds for refusal may be the lack of funds in the NIR of the CHI local fund (Law No. 326-FL, Article 38, pp. 5-9).

The conducted study shows that normalized insurance reserves are not formed in the CHI local funds in the form of reserves at all. Such a conclusion can be made turning to the forms of federal statistics ("The receipt and expenditure of local territorial funds compulsory medical insurance" the fragment is reflected in table 5). In the section on spending, the normalized insurance reserve is not reflected at all. This shows that the NIR is a financial stream that passes the accumulation stage in the form of reserve funds. This hypothesis is also confirmed by the order of the Federal Migration Service Foundation No. 227 from December 1, 2010 [5]. In this document in Art. 1 it is stated that "The normalized insurance reserve of a local fund is formed as part of the expenditure of the local fund budget to ensure the financial sustainability of compulsory health insurance", but in order No. 227 there is no any indication of how and where this reserve can be kept (highlighted by the author - the author's commentary), and by whom it may be controlled. The document only suggests the ways how it can be used.

Thus, the reserves of the CHILF (see Figure 1) listed, cannot be considered as reserves that could provide financial stability for local compulsory health insurance. It can be provided only by so-called "gratuitous receipts" from the Federal Migration Service. Local CHI structures cannot exist without them. 


\section{CONCLUSION}

A. Law No. 326-FL "On compulsory health insurance" prescribes the creation of three types of reserves within the structure of the CHILF budgets, but in practice these reserves are either not created at all or are created in such insignificant amounts that federal statistics records do not coincide.

$B$. The funds indicated in Law No. 326-FL as temporarily vacant should be placed in accordance with the requirements specified in RF Government Decree No. 1225 from December 31,2010 . They have a very small volume; however, they must be classified as perfect reserves. Moreover, they should be named as the Reserves for Cash Planning.

$C$. The means of a normalized insurance reserve cannot be considered as a reserve themselves, since they do not exist in this hypostasis. They are not placed on investment sites in order to maintain or increase their value, but are constantly used in the current turnover of the CHILF.

\section{References}

[1] On compulsory medical insurance in the Russian Federation". Federal Law of 29.11.2010 № 326-FZ. [“Ob obyazatel'nom medicinskom strahovanii v Rossijskoj Federacii”. Federal'nyj zakon ot 29.11.2010 № 326-FZ], Reference and information system ConsultantPlus, Access mode: http://www.consultant.ru/document/cons_doc_LAW_107289/

[2] "On placement of temporarily free funds of the Federal Compulsory Medical Insurance Fund and territorial funds of compulsory medical insurance" (Together with the rules for the placement of temporarily free funds of the Federal Fund of Mandatory Medical Insurance and Territorial Funds of Mandatory Medical Insurance). Decree of the Government of the Russian Federation No. 1225 of December 31, 2010 Federation ["O razmeshchenii vremenno svobodnyh sredstv Federal'nogo fonda obyazatel'nogo medicinskogo strahovaniya i territorial'nyh fondov obyazatel'nogo medicinskogo strahovaniya" (Vmeste s pravilami razmeshcheniya vremenno svobodnyh sredstv Federal'nogo fonda obyazatel'nogo medicinskogo strahovaniya i territorial'nyh fondov obyazatel'nogo medicinskogo strahovaniya). Postanovlenie Pravitel'stva Rossijskoj Federacii ot 31.12.2010 № 1225], Collection of Legislation of the Russian Federation [Sobranie zakonodatel'stva Rossijskoj Federacii], 2011, n. 2, Art. 388; 2014, n. 23, Art. 2980; n. 32, Art. 4500.

[3] "On the approval of the form No. 9-F "Information on the receipt and expenditure of non-budgetary funds of compulsory medical insurance" Order of Rosstat: from 05.02.2016 No. 49" ["Ob utverzhdenii formy № 9-F «Svedeniya o postuplenii i raskhodovanii sredstv vnebyudzhetnyh fondov obyazatel'nogo medicinskogo strahovaniya" Prikaz Rosstata: ot 05.02.2016 № 49], Reference and information system ConsultantPlus, Access

http://www.consultant.ru/document/cons_doc_LAW_193905/

[4] Receipt and expenditure of funds of territorial funds of compulsory medical insurance [Postuplenie i raskhodovanie sredstv territorial'nyh fondov obyazatel'nogo medicinskogo strahovaniya], official website Federal Service of State Statistics, Access mode: gks.ru/free_doc/new_site/population/urov/6-5.doc.

[5] "On the order of using the funds of the normalized insurance stock of the territorial fund of compulsory medical insurance" Order ФФОМС from 01.12.2010 № 227 [“O poryadke ispol'zovaniya sredstv normirovannogo strahovogo zapasa territorial'nogo fonda obyazatel'nogo medicinskogo strahovaniya" Prikaz FFOMS ot 01.12.2010 № 227], Reference and information system ConsultantPlus, Access mode: http://www.consultant.ru/cons/cgi/online.cgi?req=doc\&base=LAW\&n= $198564 \&$ rnd $=299965.172849772 \& d s t=100009 \&$ fld $=134 \# 0$. 